\title{
Isolation of Pesticide Tolerant Azotobacter Species from Rhizospheric Region of the Crop.
}

\author{
Ashwini S. Muttawar ${ }^{1}$. and V. S. Wadhai ${ }^{2}$. \\ Department of Microbiology, \\ 1,2-Sardar Patel Mahavidyalaya, Chandrapur (M.S.)-India \\ Email: spmicro1747@rediffmail.com.
}

\begin{abstract}
:
Present study was carried out to observe the effect of three different concentrations of two different pesticides viz. DDT (dichlorodiphenyltrichloroethane) and Confider at the rates of $1 \%, 2 \%$ and $3 \%$ respectively to investigate their effects on the growth and survival of non symbiotic, nitrogen fixing bacteria Azotobacter isolated from the rhizospheric soil. Azotobacter species were isolated on the basis of various morphological and biochemical tests. Mortality test and MIC test were performed to determine the effect of different concentration of pesticides i.e. DDT and Confidor on the growth of Azotobacter species. The results justify Azotobacter species isolated from soil sample which are tolerant to the pesticides can be applied as biofertilizer to increase the soil fertility. However more work needs to give attention to use pesticide resistant species of Azotobacter which are the natural soil conditioner acts as biofertilizer to increase the soil fertility which ultimately enhance crop production.
\end{abstract}

\section{Keywords:}

Azotobacter, Pesticide tolerance, Mortality testing, MIC.

\section{Introduction:}

The ever increasing pressure to increase food production to meet current demand requires protection of crops from pests. The use of pesticides, therefore inevitable and constitutes an integral part of modern crop management practice Pesticide are off three categories -inorganic, organic and biological, but the majority of herbicides is used today is organic chemicals [1]. Pesticides are applied as liquid spray on the crop to control pest. The pesticide contains a variety of organic and inorganic chemicals which affect microbial population of soil [2]. The pesticides are detoxified in the soil by adsorption and biodegradation. Pesticides can be metabolized and degraded by living organisms. One of the most important 
nitrogen fixing microorganism, the Azotobacter has been shown to be sensitive to these toxicants [6]. Azotobacter has emerged as the biggest group involved in the biocontrol of number of plants diseases they posses character which make them ideal for biological control and well adopted to rhizosphere and rhizoplan[8]. There are some species of free living N2 fixing bacteria in soil out of which Azotobacter is most abundant. Azotobacter can be use as biofertilizer in soil by which the crop yield can be increase due to the increased fertility of soil [5]. Azotobacter also produces, phiomin, riboflabin , nicotin, indona acetic acid and gibberlin. When Azotobacter is applied to seeds, germination is improved to a considerable extend, so also it controls plants diseases due to above substances produced by Azotobacter [3].

Pesticides affect soil microorganism and their biochemical processes related to soil fertility and can stimulate Azotobacter growth [4]. Some pesticides used in agriculture can be harmful to Azotobacter while some pesticides have been shown not only to inhibit the nitrogen fixation process in Azotobacter but also to reduce the bacterium respiration by $60 \%$ and hence preclude its positive effect. [7]. Due to the over use of pesticides the soil microbial flora becomes endanger which is used as a biofertilizer. So it becomes great loss for agricultural industry The aim of present study was to investigate the In vitro effect of pesticides viz. DDT and Confidor on the growth and survival of Azotobacter species in the rhizosphere and to isolate pesticide tolerant Azotobacter species.

\section{Material and methods:}

\section{Collection of soil samples-}

For the isolation of Azotobacter, soil samples were collected from the rhizospheric region of the crop, such as sample no. 1 is from the Farm soil ,sample no.2 is from Blackish sandy soil (Yard Soil),sample no.3 is from Black soil ( Garden Soil ), sample no.4 is from Oil Industry Soil ,sample no.5 is from Reddish sandy soil ( Barren Soil) from different areas of agricultural fields and surrounding of Chandrapur.

\section{Isolation of Nitrogen fixing bacteria, Azotobacter-}


1 gram of soil dissolved in $10 \mathrm{ml}$ sterile distilled water and serially diluted into six test tubes containing $9 \mathrm{ml}$ distilled water each, $1 \mathrm{ml}$ serially diluted sample of dilution was taken in sterile Petri plates and $10 \mathrm{ml}$ Azotobacter agar medium was poured and the plates were prepared by pour plate technique. The Plates were incubated at $30^{\circ} \mathrm{C}$ for $48 \mathrm{hrs}$ to get Azotobacter colonies.

\section{Characterization of Azotobacter-}

The Gram staining had been done using 48 hrs old culture of Azotobacter and all stained smear were examined microscopically under oil immersion. The motility of organism was observed by employing hanging drop method using 24 hrs old broth culture of Azotobacter. After the isolation, The isolates from soil sample. NO. 1,2,3,4 and 5, were selected for the characterization. They were identified by microscopic examination and were isolated on the selective media ie. Azotobacter agar media. Utilization of citrate as a sole source of carbon was tested in koser's citrate medium, production of acid from various carbon compounds was tested in sugar fermentation medium. Catalase formation was tested by using H2O2.Nitrate reduction was tested by nitrate and Urease test was also performed.

\section{Identification-}

Preparation of the pesticides percent solution that is DDT and confidor both i.e. $1 \%$ by taking $0.1 \mathrm{ml}$ pesticides solution in $10 \mathrm{ml}$ distilled water ,2\% by taking $0.2 \mathrm{ml}$ pesticides solution in $10 \mathrm{ml}$ distilled water, $3 \%$ by taking $0.3 \mathrm{ml}$ pesticides solution in $10 \mathrm{ml}$ distilled water. The isolated colonies were inoculated in nutrient broth medium and incubated for 24 hours at $37^{\circ} \mathrm{C}$, the growth was obtained after the incubation of $24 \mathrm{hrs}$ at $37^{\circ}$ $\mathrm{C}$ and then the pesticides were added according to their percentage composition that is $1 \%, 2 \%, 3 \%$ in $10 \mathrm{ml}$ respectively for both DDT and confidor.

\section{Pesticides Tolerant Test-}

For this the mortality test was used. In this test the broth of Azotobacter which were isolated from the different soil samples were mixed with $1 \%, 2 \%$ and $3 \%$ confidor and DDT. Then this mixture of pesticides and 
Azotobacter broth were Spread by spreder on the Azotobacter agar plates after every $24 \mathrm{hrs}$ of incubation from 0 to $144 \mathrm{hrs}$ and the numbers of colonies were counted which decreases after every 24 hrs.

\section{MIC (Minimum inhibitory concentration) of the pesticide tolerant Azotobacter species by agar cup method-}

MIC (Minimum inhibitory concentration) of the pesticide tolerant Azotobacter species is done by agar cup method in which nutrient agar plates were centrally bored by a borer. The broth culture of the isolate was spreaded with spreader and kept for 10 to 15 minutes and then pesticide $(2 \%$ and $3 \%)$ treated broth was poured in the well at for incubation at $37 \mathrm{C}$. After 24 hrs the zone of inhibition was observed around the well.

\section{Results and discussion:}

Total five samples were selected and isolated colonies appeared on Azotobacter medium were studied for size, shape, colour, margin, opacity etc. Table-1 shows the colony characteristics of isolation of species.

The identification of all five isolates from five different soil samples were carried out by observing their morphological and biochemical characteristics of isolated colonies, Table-2 shows the morphological characteristics and table no.3 shows the biochemical characteristics of isolated species and reported as,

Out of isolate of collected spices from the soil collected from the different rhizospheric region were shared all morphological and physiological characteristics, All were shown Gram negative, pink colour rod, arranged singly and having pleomorphic cocci and the motility.

In the biochemical characteristic isolates from soil sample no. 1,2,3,4 and 5 shows indole test positive while isolates from sample no.13 shows Methyl red test positive, isolates from soil sample no. 2 and 4 shows MR test negative VP test is negative form all the isolates of five soil samples no. $1,2,3,4,5$. Isolates from soil sample no. 2,3,5 gives citrate test positive where as isolates from soil sample no. 1 and 4 shows citrate negative. Catalase test is positive for all the isolates from soil samples no. 1,2,3,4,5. Triple Sugar Iron agar (TSI ) test is positive for isolates from soil sample no. 1,2 and 3 
where as it is negative for isolates from soil sample no. 3 and 4 . Urease test is positive for isolates from soil sample no. 1,3,4,5 and negative for isolates from soil sample no. 2. Nitrate test is positive for isolates from soil sample no. 1,2, and 5 were as negative for isolates from soil sample no. 3 and 4 . The sugar test i.e Glucose is positive for isolates from soil sample no. 3,4,5 with the production of acid only no gas were as negative for isolates from soil sample no. 1 and 2. Lactose fermentation is positive for isolates from soil sample no. 3 and 5 with production of acid only while isolates from soil sample no. 1,2,3 gives negative test. Mannitol fermentation shown by isolates from soil sample no. 1,3,5 and negative for others. Sucrose fermentation is positive for isolates from soil sample no. 3 and 4 to the production of acid only and other isolates shows sucrose fermentation negative

To study the pesticide tolerant test on Azotobacter species the mortality test was done, out of 5 isolates of Azotobacter ie soil sample no. $1,2,3,4,5$. Only soil sample no. 5 shows mortality test positive whose results are presented in Table-4.

All the five sample were resistance against 1\%, 2\%, 3\% DDT i.e Azotobacter is resistant against DDT and soil sample no. 1,2,3,4, shows resistance to confidor only soil sample no. 5 shows sensitivity showing decreasing no of colonies of Azotobacter. Azotobacter species isolated from soil sample no. 1,2,3,4 were tolerant to DDT and confidor, where as Azotobacter species isolated from soil sample no. 5 shows tolerance against DDT but sensitivity to confidor.

MIC (Minimum inhibitory concentration) of the pesticide tolerant Azotobacter species is done by agar cup method where the zone of inhibition was observed which varied with different concentration of DDT and Confidor, The results of MIC were presented in Table no.5,

No zone of inhibition was observed around 1\% 2\% and 3\% DDT , where as Zone of inhibiton was observed around $2 \%$ and $3 \%$ confidor and not around $1 \%$ confidor. 
Table 1: Colony characteristics of 5 isolated colonies are as follows

\begin{tabular}{|c|c|c|c|c|c|}
\hline Isolates & Size & Shape & Colour & Margin & Opacity \\
\hline 1 & $1-2 \mathrm{~mm}$ & Circular & White mucoid & entire & opaque \\
\hline 2 & $1-2 \mathrm{~mm}$ & Circular & White mucoid & entire & opaque \\
\hline 3 & $1-5 \mathrm{~mm}$ & Circular & translucent & entire & translucent \\
\hline 4 & $1-3 \mathrm{~mm}$ & Circular & White mucoid & entire & opaque \\
\hline 5 & $1-2 \mathrm{~mm}$ & Circular & White mucoid & entire & opaque \\
\hline
\end{tabular}

Table 2: Morphological characteristic of isolated colonies

\begin{tabular}{|c|c|c|c|c|c|c|}
\hline $\begin{array}{c}\text { Sr. } \\
\text { no }\end{array}$ & $\begin{array}{c}\text { Characteristics } \\
\text { of Azotobacter }\end{array}$ & $\begin{array}{c}\text { Soil. } \\
\text { Sample. } \\
\text { NO.1 }\end{array}$ & $\begin{array}{c}\text { Soil. } \\
\text { Sample. } \\
\text { NO.2 }\end{array}$ & $\begin{array}{c}\text { Soil. } \\
\text { Sample. } \\
\text { NO.3 }\end{array}$ & $\begin{array}{c}\text { Soil } \\
\text { Sample } \\
\text { NO.4 }\end{array}$ & $\begin{array}{c}\text { Soil } \\
\text { Sample } \\
\text { NO5. }\end{array}$ \\
\hline 1. & Gram Staining & $\begin{array}{c}\text { Gram } \\
\text { Negative }\end{array}$ & $\begin{array}{c}\text { Gram } \\
\text { Negative }\end{array}$ & $\begin{array}{c}\text { Gram } \\
\text { Negative }\end{array}$ & $\begin{array}{c}\text { Gram } \\
\text { Negative }\end{array}$ & $\begin{array}{c}\text { Gram } \\
\text { Negative }\end{array}$ \\
\hline 2. & Motility & $\begin{array}{c}\text { Long rods } \\
\text { sluggishly } \\
\text { motile }\end{array}$ & $\begin{array}{c}\text { Short } \\
\text { rods } \\
\text { actively } \\
\text { motile }\end{array}$ & $\begin{array}{c}\text { Long } \\
\text { rods } \\
\text { actively } \\
\text { motile }\end{array}$ & $\begin{array}{c}\text { Long } \\
\text { rods } \\
\text { actively } \\
\text { motile }\end{array}$ & $\begin{array}{c}\text { Short } \\
\text { rods } \\
\text { actively } \\
\text { motile }\end{array}$ \\
\hline
\end{tabular}

Table 3: Biochemical characteristic of isolated colonies

\begin{tabular}{|c|c|c|c|c|c|c|}
\hline $\begin{array}{l}\text { Sr. } \\
\text { no }\end{array}$ & $\begin{array}{c}\text { Characteristics of } \\
\text { Azotobacter }\end{array}$ & $\begin{array}{c}\text { Soil. } \\
\text { Sample. } \\
\text { NO.1 }\end{array}$ & $\begin{array}{c}\text { Soil. } \\
\text { Sample. } \\
\text { NO.2 }\end{array}$ & $\begin{array}{c}\text { Soil. } \\
\text { Sample. } \\
\text { NO.3 }\end{array}$ & $\begin{array}{c}\text { Soil } \\
\text { Sample } \\
\text { NO.4 }\end{array}$ & $\begin{array}{c}\text { Soil } \\
\text { Sample } \\
\text { N05. }\end{array}$ \\
\hline 1 & Indole test & Positive & Positive & Positive & Positive & Positive \\
\hline 2. & M.R.Test & Positive & Negative & Positive & Negative & Positive \\
\hline 3 & V P Test & Negative & Negative & Negative & Negative & Negative \\
\hline 4. & Citrate & Negative & Positive & Positive & Negative & Positive \\
\hline 5. & Catalas Test & Positive & Positive & Positive & Positive & Positive \\
\hline 6. & T S I & Positive & Positive & Negative & Negative & Positive \\
\hline 7. & Urease Test & Positive & Negative & Positive & Positive & Positive \\
\hline 8. & Nitrate Test & Positive & Positive & Negative & Negative & Positive \\
\hline 9. & $\begin{array}{c}\text { Sugar Fermentation } \\
\text { 1.Glucose } \\
\text { 2.Lactose } \\
\text { 3.Mannitol } \\
\text { 4.Sucrose }\end{array}$ & $\begin{array}{l}\text { Negative } \\
\text { Negative } \\
\text { Positive } \\
\text { Negative }\end{array}$ & $\begin{array}{l}\text { Negative } \\
\text { Negative } \\
\text { Negative } \\
\text { Negative }\end{array}$ & $\begin{array}{l}\text { Positive } \\
\text { Positive } \\
\text { Positive } \\
\text { Positive }\end{array}$ & $\begin{array}{l}\text { Positive } \\
\text { Negative } \\
\text { Negative } \\
\text { Positive }\end{array}$ & $\begin{array}{l}\text { Positive } \\
\text { Positive } \\
\text { Positive } \\
\text { Negative }\end{array}$ \\
\hline
\end{tabular}


Table 4: Mortality test for isolate of soil sample no. 4

\begin{tabular}{|c|c|c|c|c|c|c|c|}
\hline $\begin{array}{c}\text { Time } \\
\text { in } \\
\text { hours }\end{array}$ & $\begin{array}{c}00 \\
\text { hours }\end{array}$ & $\begin{array}{c}24 \\
\text { hours }\end{array}$ & $\begin{array}{c}48 \\
\text { hours }\end{array}$ & $\begin{array}{c}72 \\
\text { hours }\end{array}$ & $\begin{array}{c}96 \\
\text { hours }\end{array}$ & $\begin{array}{c}120 \\
\text { hours }\end{array}$ & $\begin{array}{c}144 \\
\text { hours }\end{array}$ \\
\hline \multicolumn{8}{|c|}{ DDT } \\
\hline $1 \%$ & No Growth & Growth & Growth & Growth & Growth & Growth & Growth \\
\hline $2 \%$ & No Growth & Growth & Growth & Growth & Growth & Growth & Growth \\
\hline $3 \%$ & No Growth & Growth & Growth & Growth & Growth & Growth & Growth \\
\hline \multicolumn{8}{|c|}{ Confidor } \\
\hline $1 \%$ & No Growth & Growth & Growth & Growth & Growth & Growth & Growth \\
\hline $2 \%$ & No Growth & Growth & $\begin{array}{c}\text { No of } \\
\text { colonies } \\
\text { decreases }\end{array}$ & $\begin{array}{c}\text { No of } \\
\text { colonies } \\
\text { decreases }\end{array}$ & $\begin{array}{c}\text { No of } \\
\text { colonies } \\
\text { increases }\end{array}$ & $\begin{array}{c}\text { No of } \\
\text { colonies } \\
\text { increases }\end{array}$ & $\begin{array}{l}\text { Growth } \\
\text { continues }\end{array}$ \\
\hline $3 \%$ & No Growth & Growth & $\begin{array}{c}\text { No of } \\
\text { colonies } \\
\text { decreases }\end{array}$ & $\begin{array}{c}\text { No of } \\
\text { colonies } \\
\text { decreases }\end{array}$ & $\begin{array}{c}\text { No of } \\
\text { colonies } \\
\text { decreases }\end{array}$ & $\begin{array}{c}\text { No of } \\
\text { colonies } \\
\text { increase }\end{array}$ & $\begin{array}{l}\text { Growth } \\
\text { continues }\end{array}$ \\
\hline
\end{tabular}

Table 5: The soil sample No 5 showed the following observation when the MIC (Minimum inhibitory concentration) test was performed.

\begin{tabular}{|c|c|c|c|}
\hline $\begin{array}{c}\text { Zone of } \\
\text { inhibition }\end{array}$ & $\mathbf{1 \%}$ & $\mathbf{2 \%}$ & $\mathbf{3 \%}$ \\
\hline DDT & $\begin{array}{c}\text { No zone of } \\
\text { inhibition }\end{array}$ & $\begin{array}{c}\text { No zone of } \\
\text { inhibition }\end{array}$ & $\begin{array}{c}\text { No zone of } \\
\text { inhibition }\end{array}$ \\
\hline Confidor & $\begin{array}{l}\text { No zone of } \\
\text { inhibition }\end{array}$ & $12 \mathrm{~mm}$ & $16 \mathrm{~mm}$ \\
\hline
\end{tabular}

\section{Conclusion:}

In Mortility test the number of Azotobacter colonies of isolate from soil sample no.5 gets decreases after every 24 hrs when treated with confidor while with DDT it shows resistance. This result is shown by the isolate of Azotobacters species of soil sample no. 5 against confidor with the $2 \%, 3 \%$ but not with $1 \%$ as it shows uniform growth after 144 hrs. Against DDT with $1 \%, 2 \%, 3 \%$ all the isolate of Azotobacters species from all the 5 samples shows resistance, as it shows growth after $144 \mathrm{hrs}$ as that of confidor $1 \%, 2 \%, 3 \%$ against the 4 samples that is Soil Sample no $1,2,3, \& 4$, therefore all the four samples are resistance to confidor and DDT but only the 5 samples shows sensitivity against confidor $(2 \% \& 3 \%)$ but DDT show resistance. Hence it is concluded that Azotobacter can be use as 
biofertilizer in the pesticides treated soil by which the crop yield can be increase due to the increased fertility of soil.

\section{Acknowledgement:}

Author would like to thank Principal, Sardar Patel Mahavidyalaya, Chandrapur gratefully and sincerely for his encouragement and support.

\section{References:}

[1] Anderson, (1983).Chironomidae toxicity tests--biological background and procedures. In: Aquatic invertebrate bioassays. A.L. Buikema Jr. and J. Cairns Jr., Eds., pp. 70-80. ASTM STP 715, ASTM, Philadelphia, PA. \#1980-13

[2] Ayanaba, (1981). The effect of clearing and cropping on the organic reserves and biomass of tropical forest soils. Soil biology and biochemistry 8: 519-525

[3] Das H. K., (1991). Biological nitrogen fixation in the content of Indian agriculture. Current Science, May 25, 1991, pp.551-555.

[4] Das, A. C. and D. Mukherjee., (1998), Insecticidal effects on soil microorganisms and their biochemical processes related to soil fertility, World journal of Microbiology, 14 (6) pp 903-906.

[5] Deshmukh A.M. Biofertlizers and Biopesticides abd publisher, pp. 150158.

[6] Kheri etal., (1993). Sensitivity of Azotobacter against herbicides.

[7] Santos, A., Flores M., (1995). (Effect of1995). Letters Application of Microbiology, 20 (6): pp 349-352.

[8] Subbarao, (1986). Soil Microorganism and plant growth Oxford and IBH publication Go.Pvt.Ltd. New Delhi. 